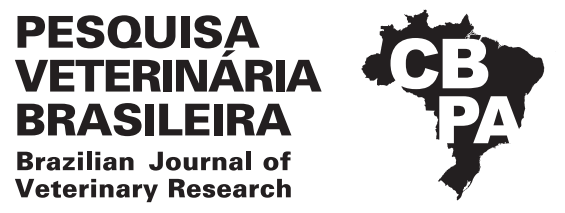

Pesq. Vet. Bras. 39(11):923-931, November 2019 DOI: 10.1590/1678-5150-PVB-6144

Original Article

Animal Morphophysiology

ISSN 0100-736X (Print)

ISSN 1678-5150 (Online)

\title{
Ultrasonographic features of the normal thyroid gland in adult horses ${ }^{1}$
}

\author{
Gustavo F. Viana² (D), Luciana Carandina², Alessandre Hataka ${ }^{3}$, Monica Midon ${ }^{4}$, \\ Camila A. Sarkis ${ }^{2}$, José N.P. Puoli Filho ${ }^{5}$ and Vânia M.V. Machado²* (D)
}

\begin{abstract}
Viana G.F., Carandina L., Hataka A., Midon M., Sarkis C.A., Puoli Filho J.N.P. \& Machado V.M.V. 2019. Ultrasonographic features of the normal thyroid gland in adult horses. Pesquisa Veterinária Brasileira 39(11):923-931. Departamento de Reprodução Animal e Radiologia Veterinária, Faculdade de Medicina Veterinária e Zootecnia, Universidade Estadual Paulista "Júlio de Mesquita Filho", Rua Prof. Dr. Walter Mauricio Correra s/n, Rubião Junior, Botucatu, SP 18618-970, Brazil. E-mail: vaniamvm@fmvz.unesp.br

Few reports have been published regarding the use of ultrasonography as a method of evaluating the normal thyroid gland in horses. For these reasons, this study aimed at determining reliably of the thyroid measurements from the comparison between the left and right thyroid lobes, as well as assessing the contour, format, echotexture and echogenicity of the healthy thyroid by mode-B ultrasonography. Additionally, the equine thyroid vascularization was quali-quantitatively characterized the by Doppler. The sample size initially was determined by the animal selection with advanced age and without volume increase in the neck proximal region. Finally, eleven horses were selected by laboratory test, search of thyroid neoformations by ultrasonography and cytology thyroid. Next, these animals were submitted to thyroid lobes ultrasonographic evaluation. Excellent reproducibility was observed for all measurements obtained. Among the comparisons made between the quantitative parameters of the left and right lobes, it was observed that there was only difference between their respective lengths. Qualitatively, there was a significant variation between the lobes elliptical format in the longitudinal plane of some glands, which oscillated between a rounded and flattened conformation. Thus, we can conclude that the difference between the lobes format of some thyroids can be explained by the significant difference observed between the length of the left and right lobes. Additionally, it was verified that there was no difference between the Doppler quantitative parameters. Therefore, we may suggest that unilateral analysis of the cranial thyroid artery by spectral Doppler can be used to evaluate equine thyroid diffuse disorders.
\end{abstract}

INDEX TERMS: Ultrasonography, thyroid gland, adult horses, thyroid lobes, ultrasound, equines, horses, morphology.

\footnotetext{
${ }^{1}$ Received on June 6, 2019.

Accepted for publication on June 13, 2019.

${ }^{2}$ Departamento de Reprodução Animal e Radiologia Veterinária, Faculdade de Medicina Veterinária e Zootecnia (FMVZ), Universidade Estadual Paulista "Júlio de Mesquita Filho" (Unesp), Rua Prof. Dr. Walter Mauricio Correra s/n, Rubião Junior, Botucatu, SP 18618-970, Brazil. *Corresponding author: vaniamvm@fmvz.unesp.br

${ }^{3}$ Departamento de Clínica Veterinária, Faculdade de Medicina Veterinária e Zootecnia (FMVZ), Universidade Estadual Paulista "Júlio de Mesquita Filho" (Unesp), Rua Prof. Dr. Walter Mauricio Correra s/n, Rubião Junior, Botucatu, SP 18618-970.

${ }^{4}$ Departamento de Cirurgia e Anestesiologia, Faculdade de Medicina Veterinária e Zootecnia (FMVZ), Universidade Estadual Paulista "Júlio de Mesquita Filho" (Unesp), Rua Prof. Dr. Walter Mauricio Correra s/n, Rubião Junior, Botucatu, SP 18618-970.

${ }^{5}$ Departamento de Produção Animal, Faculdade de Medicina Veterinária e Zootecnia (FMVZ), Universidade Estadual Paulista "Júlio de Mesquita Filho" (Unesp), Rua Prof. Dr. Walter Mauricio Correra s/n, Rubião Junior, Botucatu, SP 18618-970.
}

RESUMO.- [Características ultrassonográficas da glândula tireoide hígida em equinos adultos.] Poucas análises foram publicadas com relação ao uso da ultrassonografia como método de avaliação da glândula tireoide hígida em equinos. Alguns trabalhos incluem a determinação das dimensões e características do parênquima. Por essas razões, este estudo teve como objetivo determinar com segurança as medidas tireoidianas a partir da comparação entre o lobo tireoidiano esquerdo e direito, bem como avaliar os contornos, formato, ecotextura e ecogenicidade das glândulas tireoides hígidas pela ultrassonografia em modo B. Além disso, a vascularização da tireoide equina foi caracterizada quali-quantitativamente pela ferramenta Doppler. 0 tamanho da amostra inicialmente foi determinado pela seleção dos animais com idade avançada e sem aumento de volume na região proximal do pescoço. Por fim, onze equinos foram selecionados por meio de exame 
laboratorial, pesquisa de neoformações tireoidianas por ultrassonografia e citologia da tireoide. Em seguida, estes animais foram submetidos à avaliação de lobos tireoidianos por ultrassonografia. Observou-se excelente reprodutibilidade em relação a todas as medidas deste estudo. Foram observadas diferenças qualitativas entre os lobos tireoidianos direito e esquerdo. Assim, podemos concluir que tais diferenças entre o formato dos lobos tireoidianos podem ser explicadas pela diferença significativa e/ou tendência observada no parâmetro comprimento entre os respectivos lobos. Além disso, não foi encontrada diferença significativa entre os valores da artéria tireoidiana cranial esquerda em relação aos obtidos na artéria tireoidiana cranial direita, sugerindo que a análise dos valores espectrais do Doppler de uma das artérias tireoidianas craniais possa ser utilizada como método de avaliação de distúrbios difusos da tireoide equina.

TERMOS DE INDEXAÇÃO: Ultrassonografia, glândula tireoide, equinos adultos, lobos tireoidianos, ultrassom, cavalos, morfologia.

\section{INTRODUCTION}

The horse thyroid gland (Glandula thyreoidea), located between the third and the sixth tracheal ring, consists of two lobes immediately caudal to the larynx, usually joined by a narrow fibrous isthmus. It is not uncommon to observe a developed isthmus, exerting glandular activity on the adult horse. The thyroid is highly vascularized, receiving blood from the cranial thyroid artery, the largest branch of the common carotid artery (Venzke 1975, Budras et al. 2008).

Neoplasia is the most common finding among thyroid gland changes in horses. It is usually unilateral, derived from adenomas of parafollicular cells (C cells) and occurs mainly in aged horses (Ueki et al. 2004). Malignant neoplasias of the thyroid are less frequent and, in some cases, can be responsible for triggering hypo- or hyperthyroidism (Hillidge et al. 1992, Held et al. 1985, Ramirez et al. 1998).

Few reports have been published regarding the use of ultrasonography as evaluation methodology of normal thyroid gland in horses. Some studies include the determination of the dimensions and parenchymal characteristics (Rantanen 1998, Reef 1998, Davies et al. 2010). Despite the lack of thyroid gland normality parameters by ultrasonography, some reports described the use of ultrasound in the characterization of thyroid neoformations in horses (Elce et al. 2003, Tan et al. 2008, Saulez et al. 2013). According to Troillet et al. (2016), the ultrasonographic exam was useful for evaluation of size, relation with adjacent anatomical structures and vascularization of neoplastic thyroids submitted to thyroidectomy. In human medicine, B-mode ultrasonography associated with Doppler method has been used in order to perform a more accurate evaluation of nodular and diffused thyroid diseases (Turgut et al. 2009). This technic can provide more than $90 \%$ of diagnosis accuracy in thyroid carcinoma (Fukunari 2002). However, in veterinary medicine, there are few studies regarding the use of Doppler tool as a thyroid evaluation method. These research are restricted to the use of power Doppler function for the purpose of mainly assess the vascularization in some case reports of equine (Tan et al. 2008, Saulez et al. 2013) and canine (Taeymans 2009) thyroid neoplasms.

Therefore, a broader knowledge of the normal thyroid gland ultrasonographic features becomes necessary. For these reasons, this study aimed at (1) determining reliably of the thyroid measurements from the comparison between the left and right thyroid lobes, as well as (2) assessing the contours, formats, echotexture and echogenicity of the healthy thyroid lobes by mode-B ultrasonography; and (3) quali-quantitatively characterizing the equine thyroid gland vascularization by Doppler tool.

\section{MATERIALS AND METHODS}

Ethics statement. This study was carried out from August 2014 to June 2015, and it was approved and performed in accordance with the Ethics Committee of the "Universidade Estadual Paulista" (protocol number: 165/2013-CEUA).

Animal selection. The sample size was initially determined by the selection of animals over the age of ten (risk factor for thyropathies) and clinically certified as without apparent volume increase in the ventrolateral proximal region adjacent to the larynx. Finally, 11 horses (seven males and four females) with healthy thyroid were selected by laboratory test for evaluating the thyroid function. These animals also were submitted to search for neoformation in the thyroid parenchyma by ultrasonography. The mean age of the horses used in this study was $16( \pm 2.49)$ years and the mean weight was $403.45( \pm 36.23) \mathrm{kg}$.

Laboratory exam and search of thyroid neoformations by ultrasonography. Blood samples were sent to a specialized laboratory for the diagnosis of veterinary endocrine disorders (B.E.T. Laboratories, Rio de Janeiro, Brazil) for the determination of the free and biologically active fractions of thyroxine (free T4) by the method of radioimmunoassay (equilibrium dialysis).

A portable ultrasound apparatus (MyLab ${ }^{\mathrm{TM}}$ 30VETGold; Esaote, Genova, Italy) with an $18 \mathrm{MHz}$ multi-frequency linear transducer was used to investigate the neoformations presence in the thyroid parenchyma.

Ultrasound-guided fine needle aspiration cytology (FNAC). The cytological exam was performed after the ultrasonography studies. This permitted a more reliable evaluation of the thyroid parenchyma without any influence from acute and/or chronic inflammatory alterations originated by the perforation of the needle in the evaluated glands.

The horses were sedated through the intramuscular and intravenous administration of acepromazine $(0.05 \mathrm{mg} / \mathrm{kg})$ and xylazine hydrochloride $(0.5 \mathrm{mg} / \mathrm{kg})$, respectively.

A portable ultrasound apparatus (the same one used for searching for thyroid nodular formations by ultrasound) was used. A transversal image of the examined lobe was generated. The following materials were used in this procedure: disposable hypodermic needles $(50 \times 7 \mathrm{~mm}), 10-\mathrm{ml}$ disposable syringes and a Valeri aspirator. The needle was introduced at a 45-degree angle on the skin and was directed toward the center of the thyroid lobe. During the trajectory of the needle, the cervical portion of the parotid salivary gland and the sternocephalic muscle were surpassed so the gland could be reached.

Ultrasonography. The ultrasound apparatus was the same as the one used for the search of thyroid neoformations. The examinations were performed by a master veterinary diagnostic imaging. These studies were supervised by a Veterinary Radiology Associate Professor at "Universidade Estadual Paulista", with 20 years of experience in equine ultrasonography.

B-Mode study. The B-mode analysis for thyroid was performed with the following settings: gain, $94-100 \%$; frequency, $12-18 \mathrm{MHz}$; depth, $3-4 \mathrm{~cm}$. Only one focus was utilized, and it was regulated up to the medial margin of the gland. Initially, the transducer was positioned perpendicularly to the larynx, slipped to the proximal portion of the trachea and then displaced laterally to the left and right 
until obtaining the transverse plane of the thyroid lobes. Starting from the acquired prior image, the longitudinal plane was obtained by rotating the transducer $90^{\circ}$.

Mensuraments. The dimensions were acquired on the ultrasound apparatus itself. The width and height were determined in the transverse plane of the thyroid lobe with $18 \mathrm{MHz}$ of frequency. In the longitudinal plane, the length was obtained by total visualization of both poles (cranial and caudal), considering the greatest dimension of the lobe. The transducer was slipped $90^{\circ}$ from the initial transverse position to get these images. Slight pressure and angulations were necessary for the total visualization of the cranial and caudal poles. For this evaluation, a frequency from 12 to $18 \mathrm{MHz}$ was utilized, varying according to the general dimensions of the thyroid lobe (Fig.1).

The determination of the volume of the left thyroid lobe (VLTL) and right TL (VRTL) was estimated by the equation: length $\times$ width $\times$ height $\times \pi / 6$. The total glandular volume corresponded to the sum of the two lobes in the same animal $\left(\right.$ VLTLcm $\left.^{3}+V_{R T L c m}{ }^{3}\right)$. This formula, designed to obtain the volume of elliptical forms, has been employed in human and veterinary medicine to calculate thyroid volume (Brown \& Spencer 1978, Wisner \& Nyland 1998).

Format, contours echotexture and echogenicity. These parameters were evaluated qualitatively. For format, the approximate geometric form of the thyroid lobes was described in each image plane with its respective variations. In the longitudinal plane, the format was classified as flat and rounded. For the transverse plane, they were classified as spherical and elliptical.

The contours of the thyroid gland were evaluated according to the definition (clearly or poorly defined) and according to the regularity (regular or irregular) of their lateral and medial portions.

The images generated were used to evaluate parenchymal characteristics, such as the echogenicity and echotexture of the thyroid lobes.

Doppler study. The cranial thyroid artery (Arteria thyreoidea cranialis) was selected for the study of the thyroid lobe arterial vascularization due to its smaller anatomical variation, greater caliber and lower degree of tortuosity when compared with the branches near the thyroid lobe cranial pole and the caudal thyroid artery (Arteria thyreoidea caudalis). Additionally, the cranial thyroid artery was suitable for application of the angle of insonation (less than or equal to $60^{\circ}$ ).

The cranial thyroid artery was accessed in the longitudinal plane by displacing the transducer from the thyroid cranial pole to the medial aspect of the mandibular angle (Angulus mandibulae). Spectral Doppler was triggered after the precise identification of the cranial thyroid artery through the color Doppler in middle third of the vessel, at the thyroid lobe level.

For the color Doppler analysis, the apparatus was calibrated with a gain of $68-78 \%$ and a pulse repetition frequency (PRF) of $1.0-1.4 \mathrm{KHz}$. For the assessment by spectral Doppler, the apparatus was calibrated with a PRF of $2.8-4.2 \mathrm{KHz}$ and with a wall filter of $50 \mathrm{~Hz}$. The size of the sample volume was regulated according to the diameter of the cranial thyroid artery. The frequencies for color and spectral Doppler analyses ranged from 6.6 to $8.0 \mathrm{MHz}$.

From the Doppler protocols mentioned, quantitative and qualitative parameters were determined. By spectral Doppler, the means of the peak systolic velocity (PSV), pulsatility index (PI) and resistivity index (RI) of the left and right cranial thyroid artery were automatically calculated by the ultrasound apparatus starting from three pulses of arterial waves. The laminar flow velocity profile and the cranial thyroid artery waveforms were determined via spectral Doppler analysis.

The architecture of the blood flow of the thyroid parenchyma was characterized by a color Doppler study. For a better study of blood irrigation, each thyroid lobe was evaluated in the cranial, middle and caudal regions.

Statistical analysis. B-Mode and Doppler measurements were calculated by the analyses of three observers with at least five years of experience in veterinary ultrasonography.

All the statistical analyses were performed by using the Statistical Package for Social Sciences (IBM SPSS Statistics - version 24.0; SPSS Inc., Chicago/IL, EUA). The Kolmogorov-Smirnov statistical test was applied in order to verify a data normal distribution. Student's t test was utilized to compare the means of the right and left cranial thyroid arteries.

The interobserver reproducibility was used to evaluate the reliability of the measurements made by intraclass correlation coefficient. This coefficient was used for data analysis and classification, as proposed by Fleiss et al. (2003) (Table 1).

Table 1. Rating of interobserver agreement according to the intraclass correlation coefficient

\begin{tabular}{cc}
\hline Intraclass correlation coefficient & Interobserver agreement \\
\hline$<40$ & Poor \\
$0.40-0.75$ & Moderate \\
$0.75-1.00$ & Excellent
\end{tabular}

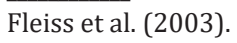
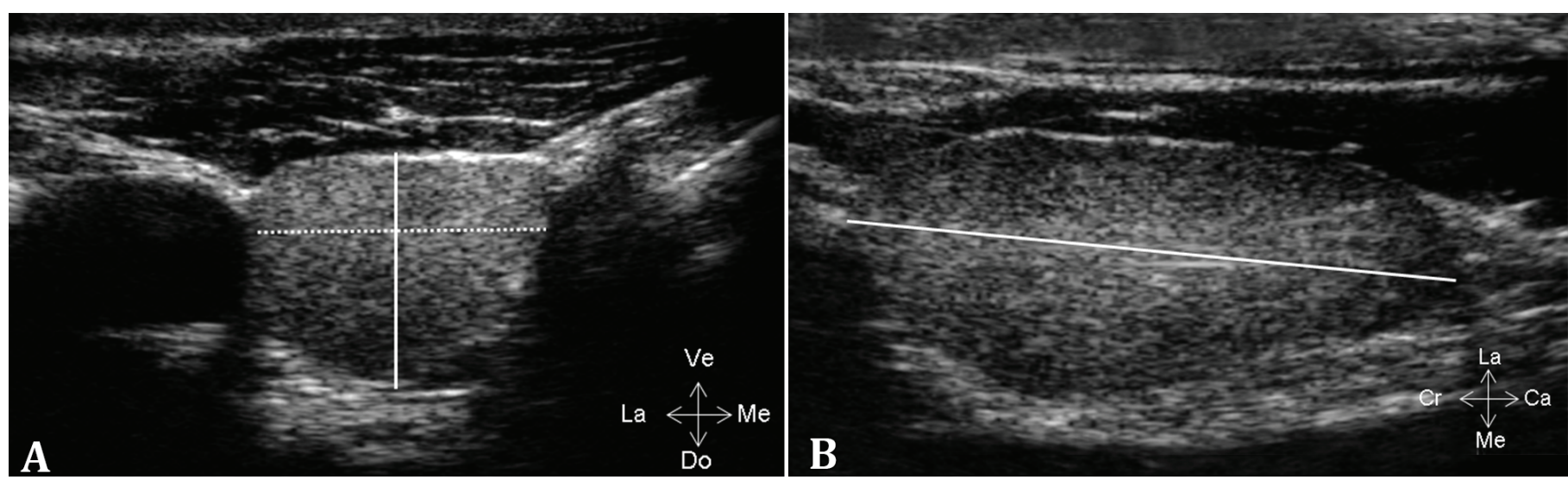

Fig.1. Thyroid lobe in the (A) transverse and (B) longitudinal planes by ultrasonography. (A) The height and width are represented by continuous and dotted lines, respectively. (B) The length is represented by a continuous line (largest axis). Dorsal (Do), lateral (La), medial (Me), ventral (Ve). 


\section{RESULTS}

\section{Animal selection}

The free T4 levels showed a mean of $1.49( \pm 0.43) \mathrm{ng} / \mathrm{dl}$ (normal values range from 0.62 to $3.03 \mathrm{ng} / \mathrm{dl}$ ). One horse got levels above the limit $(6.04 \mathrm{ng} / \mathrm{dl})$ and it was excluded from the experiment. In the screening for thyroid nodular formations by ultrasound, one horse presented a nodular formation of $0.5 \mathrm{~cm}$ in height $\times 0.58 \mathrm{~cm}$ in width $\times 0.77 \mathrm{~cm}$ in length in the caudal portion of the right thyroid lobe. There were poorly defined contours, mixed echogenicity and discretely heterogeneous echotexture, compared to the adjacent thyroidal tissue. No significant vascularization was observed in the Doppler study. This animal was excluded from the study.

Finally, by ultrasound-guided FNAC, none of the slides presented alterations related to inflammatory, dysplastic, neoplastic or degenerative processes.

\section{Ultrasonography}

B-Mode study. The descriptive statistic values for width, height and volume did not differ significantly between the right and left thyroid lobes for all the observers. A significant difference was found related to the length parameter between the left and right thyroid lobes by Observers 1 and 2 (Table 2).

On the other hand, no significant difference was observed between the length of the left and right thyroid lobes by Observer 3. However, we can suggest that there was a tendency for this result to become statistically different, since this value was very close to 0.05 . A fact that did not occur with the other parameters evaluated in this study (Table 2).

The reproducibilities were homogeneous and achieved an excellent reliability for the values obtained for the observers pairs (Table 3).

The means for the total volume of the thyroid gland calculated by ultrasonography were $13.03( \pm 4.91), 13.14( \pm 5.39)$ and $12.44( \pm 5.16)$ by Observers 1,2 and 3 , respectively.

The relation between the horses' weight and the total thyroid gland volume was evaluated. A moderate relation was observed between these variables: Observers $1(33 \%)$, $2(32 \%)$ and 3 (36\%) (Fig.2).

In the transverse plane of the thyroid lobes presented a spherical form, and in some cases, it presented a discrete projection toward the thyroid lobe medial aspect (toward the margin of the trachea).

Table 2. The descriptive statistics and comparison between the left (Lt) and right (Rt) thyroid lobes according to the ultrasound parameters in a total of 11 horses with an average weight of $403.45( \pm 36.23)$ kilograms

\begin{tabular}{|c|c|c|c|c|c|c|c|}
\hline & \multirow{2}{*}{ Site } & \multicolumn{2}{|c|}{ Observer 1} & \multicolumn{2}{|c|}{ Observer 2} & \multicolumn{2}{|c|}{ Observer 3} \\
\hline & & Mean \pm SD & $\mathrm{P}$ & Mean \pm SD & $\mathrm{P}$ & Mean \pm SD & $\mathrm{P}$ \\
\hline \multirow[t]{2}{*}{ W } & Lt & $1.97 \pm 0.37$ & 0.571 & $2.07 \pm 0.44$ & 0.238 & $1.97 \pm 0.34$ & 0.255 \\
\hline & Rt & $1.90 \pm 0.36$ & & $1.89 \pm 0.41$ & & $1.84 \pm 0.35$ & \\
\hline \multirow[t]{2}{*}{$\mathrm{H}$} & $\mathrm{Lt}$ & $1.66 \pm 0.34$ & 0.924 & $1.63 \pm 0.34$ & 0.644 & $1.61 \pm 0.36$ & 0.716 \\
\hline & $\mathrm{Rf}$ & $1.67 \pm 0.27$ & & $1.59 \pm 0.25$ & & $1.58 \pm 0.29$ & \\
\hline \multirow[t]{2}{*}{ L } & Lt & $3.85 \pm 0.44$ & $0.049 *$ & $3.90 \pm 0.42$ & $0.027^{*}$ & $3.85 \pm 0.51$ & 0.079 \\
\hline & Rt & $3.59 \pm 0.33$ & & $3.66 \pm 0.34$ & & $3.64 \pm 0.34$ & \\
\hline \multirow[t]{2}{*}{ V } & Lt & $6.96 \pm 3.06$ & 0.217 & $7.19 \pm 3.38$ & 0.110 & $6.69 \pm 3.06$ & 0.121 \\
\hline & Rt & $6.11 \pm 2.19$ & & $5.95 \pm 2.43$ & & $5.75 \pm 2.37$ & \\
\hline
\end{tabular}

$\mathrm{SD}=$ Standard deviation, $\mathrm{W}=$ width $(\mathrm{cm}), \mathrm{H}=$ height $(\mathrm{cm}), \mathrm{L}=$ length $(\mathrm{cm}), \mathrm{V}=$ volume $\left(\mathrm{cm}^{3}\right)$; * statistical $\mathrm{t}$ test of paired samples $\mathrm{t}$ for $\mathrm{P}<0.05$.

Table 3. The means of the intraclass correlation coefficients with $95 \%$ confidence intervals for ultrasound dimensions by interobserver agreement

\begin{tabular}{|c|c|c|c|c|}
\hline & \multicolumn{4}{|c|}{ Interobserver agreement } \\
\hline & \multirow{2}{*}{ Site } & Observers 1 and 2 & Observers 1 and 3 & Observers 2 and 3 \\
\hline & & ICC (CI at $95 \%)$ & ICC (CI at $95 \%)$ & ICC (CI at 95\%) \\
\hline \multirow[t]{2}{*}{ W } & Lt & $0.879(0.551-0.967)$ & $0.973(0.900-0.993)$ & $0.913(0.677-0.977)$ \\
\hline & Rt & $0.980(0.924-0.995)$ & $0,986(0,950-0.996)$ & $0.961(0.854-0.989)$ \\
\hline \multirow[t]{2}{*}{$\mathrm{H}$} & Lt & $0.996(0.986-0.999)$ & $0.997(0.987-0.999)$ & $0.994(0.976-0.998)$ \\
\hline & $\mathrm{Rf}$ & $0.983(0.935-0.995)$ & $0.971(0.893-0.992)$ & $0.970(0.887-0.992)$ \\
\hline \multirow[t]{2}{*}{$\mathrm{L}$} & Lt & $0.971(0.891-0.992)$ & $0.971(0.892-0.992)$ & $0.925(0.720-0.980)$ \\
\hline & Rt & $0.972(0.894-0.992)$ & $0.963(0.864-0.990)$ & $0.942(0.784-0.984)$ \\
\hline \multirow[t]{2}{*}{$\mathrm{V}$} & Lt & $0.967(0.877-0.991)$ & $0.996(0.986-0.999)$ & $0.971(0.892-0.992)$ \\
\hline & Rt & $0.988(0.956-0.997)$ & $0.992(0.971-0.998)$ & $0.988(0.955-0.997)$ \\
\hline
\end{tabular}

$\overline{\text { ICC }=\text { Intraclass correlation coefficients, CI at 95\% }}=95 \%$ confidence intervals, $\mathrm{W}=$ width $(\mathrm{cm}), \mathrm{H}=\mathrm{height}(\mathrm{cm}), \mathrm{L}=$ length $(\mathrm{cm}), \mathrm{V}=\mathrm{volume}\left(\mathrm{cm}{ }^{3}\right)$. 


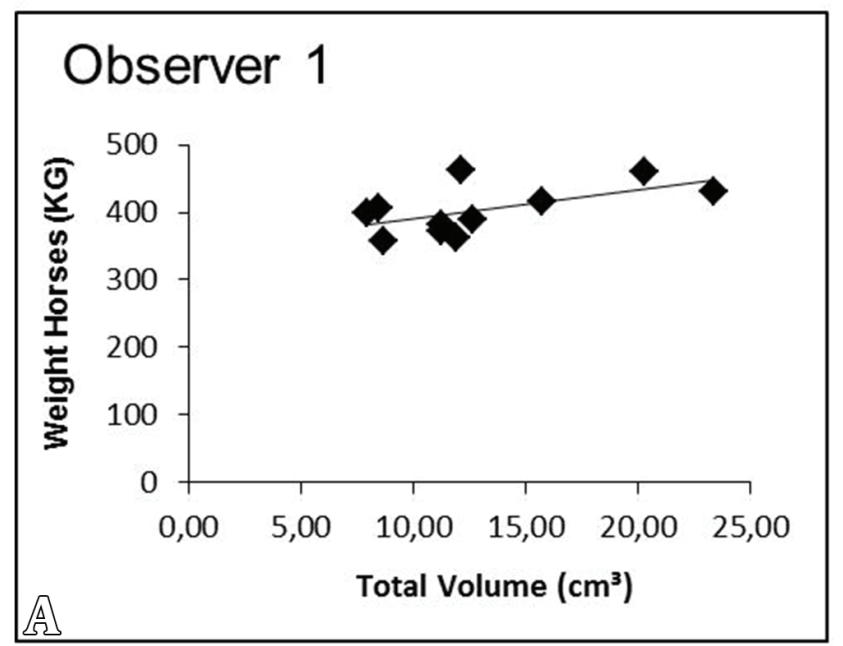

\section{Observer 2}

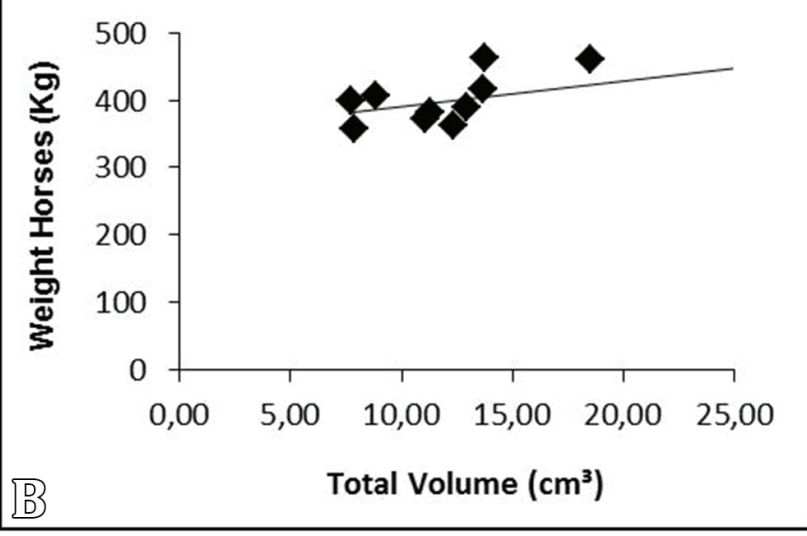

\section{Observer 3}

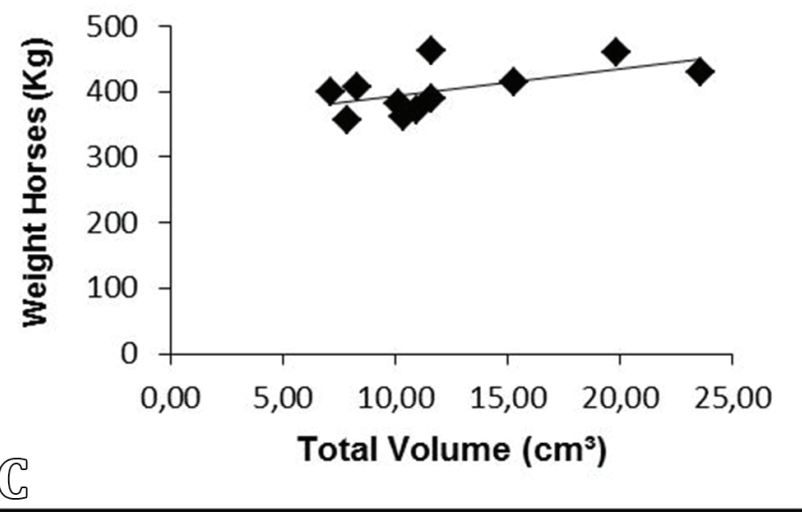

Fig.2. Relation between the thyroid gland total volume and horses' body weight by Observers $1\left(R^{2}=0.33\right), 2\left(R^{2}=0.32\right)$ and $3\left(R^{2}=0.36\right)$. Lines represent linear regression line. Ultrasonography (USG), regression coefficient $\left(\mathrm{R}^{2}\right)$.
In the longitudinal plane, a high variation related to the elliptical format of the thyroid lobes was observed, oscillating between a rounded and flattened conformation (Fig.3). Six animals presented the lobes format of some thyroids with similar formats (right lobe similar to left lobe (54.54\%) and five horses presented pair of thyroid lobes with different formats $(45.46 \%)$.

Regarding the contours, 19 thyroid lobes had regular. One left and one right thyroid lobe were slightly irregular. Only one thyroid lobe (right) was shown to be moderately irregular.

All of the evaluated thyroid glands presented a slightly heterogeneous echotexture. Regarding the echogenicity, nineteen lobes (86.36\%) displayed hyperechogenicity (Fig.3A,B,D) and two left lobes $(9.09 \%)$ and one right lobe $(4.55 \%)$ presented isoechogenicity in relation to the sternocephalic muscle (Fig.3C).

Doppler study. By spectral Doppler evaluation, the cranial thyroid arteries presented a parabolic flow velocity profile. The waveforms presented a flow pattern of low resistance, which is characterized by wide continuous systolic peaks and a high diastolic with a gradual reduction velocity. The beginning of the cranial thyroid artery waves tracing was characterized by the formation of a double systolic peak, with the second peak presenting higher amplitude (Fig.4).

No significant difference was observed between the spectral Doppler values of the left and right cranial thyroid arteries obtained by Observers 1, 2 and 3 (Table 4). In general, the Doppler parameters showed an excellent reproducibility among the three observers. However, these values were heterogeneous among pairs of evaluators (Table 5).

Color Doppler enabled a good characterization of the cranial, middle and caudal vascularization of the thyroid lobes in the longitudinal plane. The cranial thyroid artery and your branches were observed close to the cranial lobe of the thyroid lobes. The branches presented tortuous and discreetly calibrated (Fig.5A,B). The thyroid gland intralobar vessels presented a more evident vascularization in the medial portion of the gland than in the central and lateral regions (Fig.5D-F). These vessels were branched from the peripheral to the central regions and were a little tortuous through the thyroid parenchyma.

\section{DISCUSSION}

The parotid gland is the largest salivary gland of the horse. It occupies the space between the caudal border of the mandible, the wing of the atlas, and the base of the ear. Ventrally it extends to the linguofacial vein (Budras et al. 2008) place where the thyroid lobes are located. Thus, it becomes difficult to perform the ultrasound-guided FNAC of the thyroid without surpassing the parotid gland, in order to avoid the possibility of migration neoplastic cells from the thyroid to the parathyroid.

The observed echotexture and echogenicity of the equine thyroid gland were similar to those of previous descriptions (Rantanen 1998, Davies et al. 2010).

A significant difference regarding the length parameter between the left and right thyroid lobes was verified by Observers 1 and 2 and a tendency of these values to present a significant difference was noticed by Observers 3 (Table 2). The differences observed between the dimensions of the contralateral thyroid lobes could be reinforced by a previous 

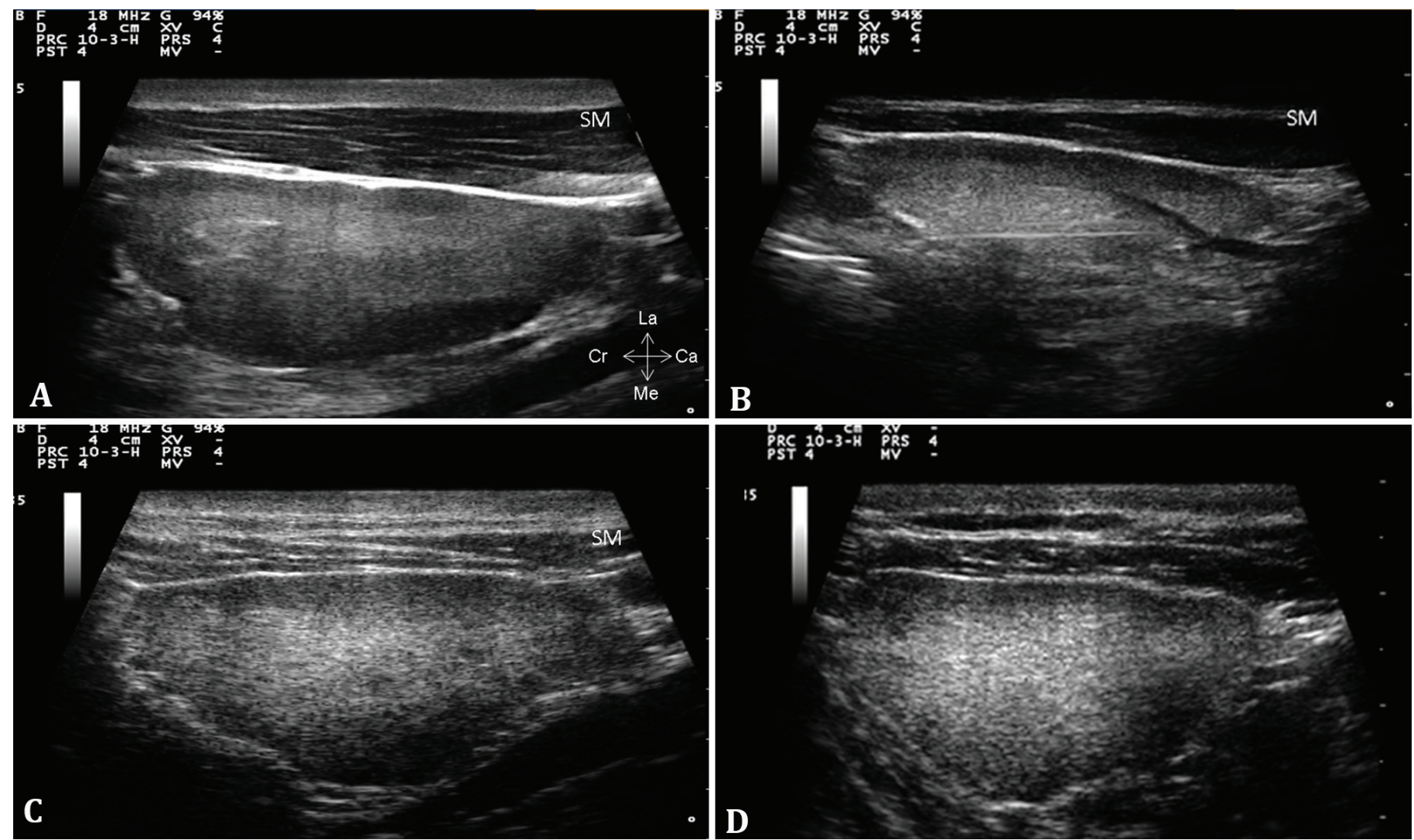

Fig.3. Presentation of the thyroid lobe formats, showing a pair of lobes with distinct aspects: (A) left side, (B) right side; and another pair of similar lobes (C) left side, (D) right side. (A,B,D) The gland is hyperechogenic in relation to the sternocephalic muscle (SM). (C) The lobe is isoecogenic in relation to the SM.

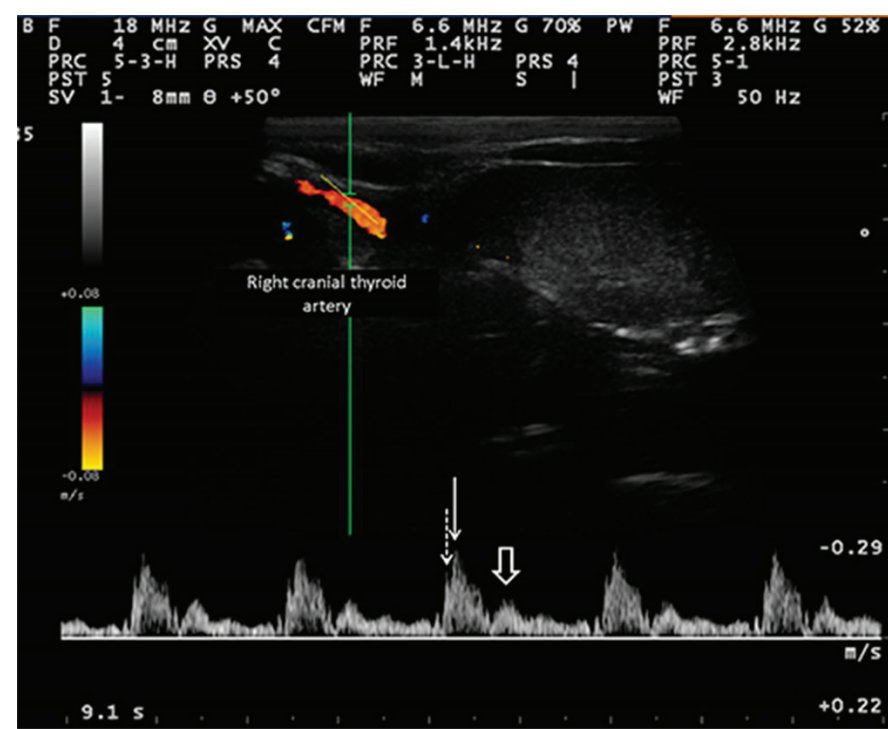

Fig.4. Spectral Doppler of cranial thyroid artery $(\mathrm{PRF}=2.8 \mathrm{KHz}$ angle $50^{\circ}$ ). The dotted and continuous arrows indicate a double systolic peak, with the second showing greater amplitude (early systolic peak, ESP). The velocity distribution is broad, without a spectral window, characterizing a parabolic flow velocity profile. The velocity decreases suddenly after the systolic peak but without diastolic reverse flow. Next, a high-velocity wave is observed (empty arrow), followed by gradual reduction of velocity, which characterizes the waveforms with a low-resistance flow pattern. study involving ultrasonographic evaluation of Golden Retriever dogs with healthy thyroid glands and hypothyroidism. It was verified that there was a significant difference between the height of the healthy thyroid lobes on the left and right sides (Bromel et al. 2005).

In contrast to the reproducibility analyses performed in this study, an evaluation of the ultrasound measurement variability between different observers of canine thyroid found that the length presented the biggest variation (poor agreement) among them (Taeymans et al. 2005).

The discrete differences observed between thyroid lobes by transverse plane were not significant, as no differences were found between the width and height of the left and right thyroid lobes for the three observers. The difference of format observed between the left and right thyroid lobes could be explained by a significant tendency of the three observers' values to be different. Thus, the height, width and volume of a healthy thyroid lobe can be used more safely than length as reference parameters for evaluation an altered contralateral thyroid lobe in horses. Although it has been shown that radiological measurements performed in small animals cannot be used to evaluate organ changes (Lamb \& Nelson 2015), based on the present results, quantitative parameters may serve as a basis for elucidating questions regarding the variation of the format of the unhealthy thyroid lobe.

The Doppler study of the thyroid vascularization confirmed anatomical information previously described by Venzke (1975), 
Table 4. The descriptive statistics and comparison between the left (Lt) and right (Rt) cranial thyroid arteries according to the parameters of spectral Doppler ultrasonography in a total of 11 horses with an average weight of $403.45( \pm 36.23)$ kilograms

\begin{tabular}{|c|c|c|c|c|c|c|c|}
\hline & \multirow{2}{*}{ Site } & \multicolumn{2}{|c|}{ Observer 1} & \multicolumn{2}{|c|}{ Observer 2} & \multicolumn{2}{|c|}{ Observer 3} \\
\hline & & Mean \pm SD & $\mathrm{P}$ & Mean \pm SD & $\mathrm{P}$ & Mean \pm SD & $\mathrm{P}$ \\
\hline \multirow[t]{2}{*}{ PSV } & Lt & $22.99 \pm 5.74$ & 0.981 & $24,04 \pm 6.02$ & 0.976 & $21.72 \pm 5.46$ & 0.529 \\
\hline & Rt & $22.92 \pm 8.85$ & & $23,95 \pm 8.84$ & & $23.19 \pm 9.41$ & \\
\hline \multirow[t]{2}{*}{ RI } & Lt & $0.71 \pm 0.10$ & 0.089 & $0.73 \pm 0.10$ & 0.081 & $0.76 \pm 0.10$ & 0.085 \\
\hline & Rt & $0.76 \pm 0.09$ & & $0.78 \pm 0.05$ & & $0.82 \pm 0.05$ & \\
\hline PI & Rt & $2.07 \pm 0.57$ & & $2.16 \pm 0.66$ & & $2.10 \pm 0.65$ & \\
\hline
\end{tabular}

$\mathrm{SD}=$ Standard deviation, $\mathrm{PSV}=$ peak systolic velocity $(\mathrm{cm} / \mathrm{sec}), \mathrm{PI}=$ pulsatility index, $\mathrm{RI}=$ resistive index; statistical $\mathrm{t}$ test of paired samples $\mathrm{t}$ for $\mathrm{p}<0.05$.

Table 5. The means of the intraclass correlation coefficients with $\mathbf{9 5 \%}$ confidence intervals for spectral Doppler ultrasound parameters by interobserver agreement

\begin{tabular}{|c|c|c|c|c|}
\hline & \multicolumn{4}{|c|}{ Interobserver agreement } \\
\hline & \multirow{2}{*}{ Site } & Observers 1 and 2 & Observers 1 and 3 & Observers 2 and 3 \\
\hline & & ICC (CI at 95\%) & ICC (CI at 95\%) & ICC (CI at $95 \%)$ \\
\hline \multirow[t]{2}{*}{ PSV } & Lt & $0.846(0.429-0.959)$ & $0.805(0.275-0.948)$ & $0.790(0.220-0.944)$ \\
\hline & Rt & $0.792(0.226-0.944)$ & $0.989(0.958-0.997)$ & $0.974(0.903-0.993)$ \\
\hline \multirow[t]{2}{*}{ RI } & $\mathrm{Lt}$ & $0.990(0.964-0.997)$ & $0.929(0.738-0.981)$ & $0.954(0.828-0.988)$ \\
\hline & Rt & $0.991(0.967-0.998)$ & $0.761(0.110-0.936)$ & $0.793(0.232-0.944)$ \\
\hline \multirow[t]{2}{*}{ PI } & Lt & $0.952(0.822-0.987)$ & $0.855(0.462-0.961)$ & $0.914(0.680-0.977)$ \\
\hline & Rt & $0.786(0.205-0.942)$ & $0.836(0.391-0.956)$ & $0.801(0.261-0.947)$ \\
\hline
\end{tabular}

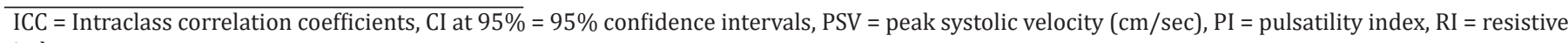
index.
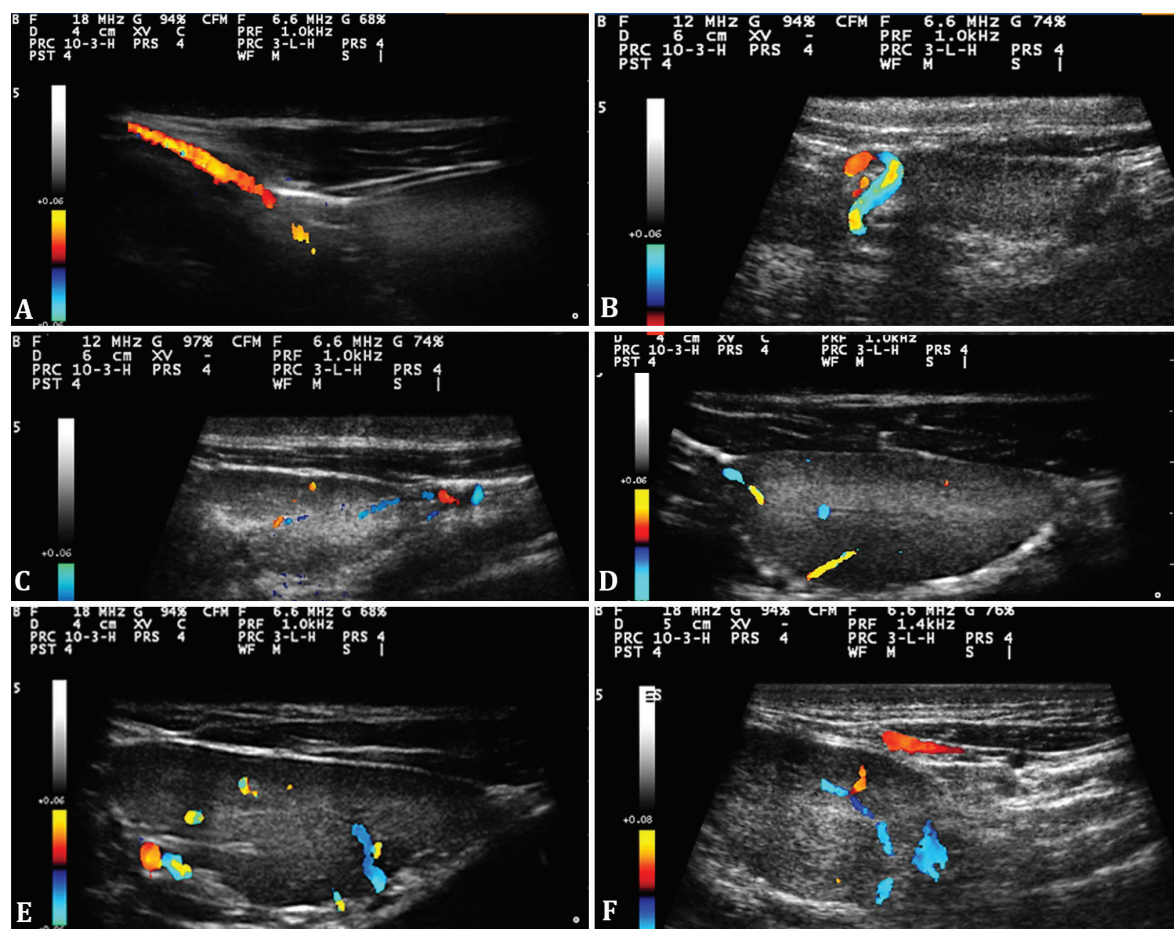

Fig.5. Vascularization assessment in the cranial, middle and caudal regions of the thyroid lobe by color Doppler. (A) Calibrated and non-tortuous cranial thyroid artery directed towards the cranial pole of the thyroid lobe. (B) The tortuous branch of the cranial thyroid artery is highlighted proximal to the cranial pole of the thyroid lobe. (C) The caudal thyroid artery supplying the thyroid lobe in its caudal portion. Intralobar vessel characteristics of the (D) cranial, (E) middle and (F) caudal regions of the thyroid lobe. 
which emphasized that the equine cranial thyroid artery is a calibrous vessel that curves over the cranial pole of the thyroid lobe emitting several branches; and that the caudal thyroid artery is a small inconstant vessel that irrigates the caudal portion of the lobes.

In the spectral Doppler analysis of the cranial thyroid artery, the visualization of a low peak preceding a second peak of greater amplitude (early systolic peak, ESP) is a characteristic of low resistance arteries. These vessels supply organs that present a continuous demand for blood, and this demand can change according to the functional status of the organs, with consequent alterations of the Doppler flow pattern. In the case of thyroid hormonal disturbances, variations in the Doppler flow pattern of the cranial thyroid artery may be detected, indicating the presence of thyroid disorders with an abnormal release of thyroidal hormones (Szatmári et al. 2001, Chiou et al. 2006).

It is possible to observe several studies in human ultrasonography using reproducibility as methodology for the validation of their data from a single observer and then analyzed by different observers (Järvelä et al. 2003, Raine-fenning et al. 2003, Moron et al. 2010). This same methodology was applied in the present study, justifying the reliability of the measurements made by all of the observers.

The interobserver agreement for the Doppler parameters was concordant but with heterogeneous values. The discrete variations of the systolic peak and final diastole determined by the three observers may have contributed to this heterogeneity. However, a reliable reproducibility was achieved, suggesting that the measurement variations did not interfere with the Doppler tool application in the equine cranial thyroid artery. Considering that the diagnostic accuracy of a method is an essential resource for determining its usefulness, validation of the reproducibility of the Doppler parameters becomes useful for the identification of hemodynamic changes (Leão et al. 2008).

\section{CONCLUSIONS}

We can conclude that there was an excellent reproducibility for thyroid quantitative parameters obtained by ultrasonography in B-mode and Doppler.

Among the comparisons made between the quantitative parameters of the left and right lobes, it was observed that there was only difference between their respective lengths. Qualitatively, there was a significant variation between the lobes elliptical format in the longitudinal plane of some glands, which oscillated between a rounded and flattened conformation. Thus, we can infer that the difference between the lobes format of some thyroids can be explained by the significant difference observed between the length of the left and right lobes.

Additionally, it was verified that there was no difference between the Doppler quantitative parameters. Therefore, we may suggest that unilateral analysis of the cranial thyroid artery by spectral Doppler can be used to evaluate equine thyroid diffuse disorders.

Acknowledgements.- The authors thank the São Paulo Research Foundation (FAPESP) for its financial support. We also thank The National Counsel of Technological and Scientific Development (CNPq) and Coordination of Improvement of Higher Level Personnel (CAPES) for encouraging the execution of this work.
Conflict of interest statement.- The authors have no competing interests.

\section{REFERENCES}

Brömel C., Pollard R.E., Kass P.H., Samii V.F., Davidson A.P. \& Nelson R.W. 2005. Ultrasonographic evaluation of the thyroid gland in healthy, hypothyroid, and euthyroid Golden Retrievers with nonthyroidal illness. J. Vet. Intern. Med. 19(4):499-506. <http://dx.doi.org/10.1111/j.1939-1676.2005. tb02718.x ><PMid:16095166>

Brown M.C. \& Spencer R. 1978. Thyroid gland volume estimated by use of ultrasound in addition to scintigraphy. Acta Radiol. Oncol. Radiat. Phys. Biol. 17(4):337-341. <http://dx.doi.org/10.3109/02841867809127937> $<$ PMid:717046>

Budras K.D., Sack W.O. \& Rock S. 2008. Head, p.38-50. In: Budras K.D., Sack W.O. \& Rock S. (Eds), Anatomy of the Horse. 5th ed. Schlütersche, Germany.

Chiou S.-C., Peng Y.-S., Chen P.-Y., Ho C., Yeh H.-Y., Chen C.-P. \& Lin J.-D. 2006. Color Doppler ultrasonography of inferior thyroid artery and its relation with thyroid functional state. J. Med. Ultrasound 14(3):51-57. <http:// dx.doi.org/10.1016/S0929-6441(09)60091-6>

Davies S., Barber D., Crisman M., Tan R., Larson M. \& Daniel G. 2010. Quantitative pertechnetate thyroid scintigraphy and the ultrasonographic appearance of the thyroid gland in clinically normal horses. Vet. Radiol. Ultrasound 51(6):674-680. <http://dx.doi.org/10.1111/j.1740-8261.2010.01721. $\mathrm{x}>\langle$ PMid:21158246>

Elce Y.A., Ross M.W., Davidson E.J. \& Tulleners E.P. 2003. Unilateral thyroidectomy in 6 horses. Vet. Surg. 32(2):187-190. <http://dx.doi.org/10.1053/ jvet.2003.50017><PMid:12692764>

Fleiss J.L., Levin B. \& Paik M.C. 2003. The measurement of interrater agreement, p.598-626. In: Fleiss J.L., Levin B. \& Paik M.C. (Eds), Statistical Methods for Rates and Proportions. 5th ed. John Wiley and Sons, New Jersey. <http:// dx.doi.org/10.1002/0471445428.ch18>

Fukunari N. 2002. Thyroid ultrasonography B-mode and color-Doppler. Biomed. Pharmacother. 56(Suppl.1):55-59. <http://dx.doi.org/10.1016/ S0753-3322(02)00213-5><PMid:12487253>

Held J.P., Patton C.S., Toal R.L. \& Geiser D.R. 1985. Work intolerance in a horse with thyroid carcinoma. J. Am. Vet. Med. Assoc. 187(10):1044-1045. <PMid:4066461>

Hillidge C.J., Sanecki R.K. \& Theodorakis M.C. 1992. Thyroid carcinoma in a horse. J. Am. Vet. Med. Assoc. 181(7):711-714. <PMid:7141970>

Järvelä I.Y., Sladkevicius P., Tekay A.H., Campbell S. \& Nargund G. 2003. Intraobserver and interobserver variability of ovarian volume, gray-scale and color flow indices obtained using transvaginal three-dimensional power Doppler ultrasonography. Ultrasound Obstet. Gynecol. 21(3):277-282. <http://dx.doi.org/10.1002/uog.62> <PMid:12666224>

Lamb C.R. \& Nelson J.R. 2015. Diagnostic accuracy of tests based on radiologic measurements of dogs and cats: a systematic review. Vet. Radiol. Ultrasound 56(3):231-244. <http://dx.doi.org/10.1111/vru.12217><PMid:25339347>

Leão A.R.S., Santos J.E.M., Moulin D.S., Shigueoka D.C., Colleoni R. \& D'Ippolito G. 2008. Portal blood flow volume measurement in schistosomal patients: evaluation of Doppler ultrasonography reproducibility. Radiol. Bras. 41(5):305-308.

Moron A.F., Milani H.J.F., Barreto E.Q.S., Araujo Júnior E., Haratz K.K., Rolo L.C. \& Nardozza L.M. 2010. Analysis of three-dimensional power Doppler sonography reproducibility in the assessment of fetal brain circulation. Radiol. Bras. 43(6):369-374. <http://dx.doi.org/10.1590/S010039842010000600007>

Raine-fenning N.J., Campbell B.K., Clewes J.S., Kendall N.R. \& Johnson I.R. 2003. The reliability of virtual organ computer-aided analysis (VOCAL) for the semiquantification of ovarian, endometrial and subendometrial perfusion. Ultrasound Obstet. Gynecol. 22(6):633-639. <http://dx.doi. org/10.1002/uog.923><PMid:14689538> 
Ramirez S., McClure J.J., Moore R.M., Wolfsheimer K.J., Gaunt S.D., Mirza M.H. \& Taylor W. 1998. Hyperthyroidism associated with a thyroid adenocarcinoma in a 21-year-old gelding. J. Vet. Intern. Med. 12(6):475-477.<http://dx.doi. org/10.1111/j.1939-1676.1998.tb02153.x><PMid:9857342>

Rantanen N.W. 1998. Ultrasound of the endocrine system, p.645-647. In: Ratanen N.W. \& McKinnon A.O. (Eds), Equine Diagnostic Ultrasonography. Williams and Wilkins, Baltimore.

Reef V.B. 1998. Ultrasonographic evaluation of small parts, p.480-487. In: Reef V.B. (Ed.), Equine Diagnostic Ultrasound. W.B. Saunders, Philadelphia.

Saulez M.N., Viljoen A., Kafka U., Rubio-Martinez L., van Wilpe E. \& Steyl J. 2013. The use of nuclear imaging for a mixed C cell microfollicular carcinoma of the thyroid gland in a mature horse. Equine Vet. Educ. 25(3):118-125. <http://dx.doi.org/10.1111/j.2042-3292.2012.00405.x>

Szatmári V., Sótonyi P. \& Voros K. 2001. Normal duplex doppler waveforms of major abdominal blood vessels in dogs: a review. Vet. Radiol. Ultrasound 42(2):93-107. <http://dx.doi.org/10.1111/j.1740-8261.2001.tb00911. $\mathrm{x}><$ PMid:11327368>

Taeymans 0. 2009. Thyroid ultrasound in dogs: a review. Ultrasound 17(3):137143. <http://dx.doi.org/10.1179/174313409X448534>

Taeymans O., Duchateau L., Schreurs E., Kramer M., Daminet S. \& Saunders J.H. 2005. Intra - and interobserver variability of ultrasonographic measurements of the thyroid gland in healthy beagles. Vet. Radiol. Ultrasound
46(2):139-142. <http://dx.doi.org/10.1111/j.1740-8261.2005.00027.x> $<$ PMid:15869158>

Tan R.H.H., Davies S.E., Crisman M.V., Coyle L. \& Daniel G.B. 2008. Propylthiouracil for treatment of hyperthyroidism in a horse. J. Vet. Intern. Med.22(5):1253-1258.<http://dx.doi.org/10.1111/j.1939-1676.2008.0169. x> <PMid:18691365>

Troillet A., Bottcher D., Brehm W. \& Scharner D. 2016. Retrospective evaluation of hemithyroidectomy in 14 horses. veterinary surgery. Vet. Surg. 45(7):949954. <http://dx.doi.org/10.1111/vsu.12540> <PMid:27598400>

Turgut A.T., Çakal E., Koşar U., Koșar P., Demirbaş B. \& Aral Y. 2009. Maximum systolic velocity of inferior thyroid artery and thyroideal color doppler flow pattern in hypothyroid subjects before and after treatment. J. Med. Ultrasound 17(1):44-51. <http://dx.doi.org/10.1016/S0929-6441(09)60014-X>

Wisner E.R. \& Nyland T.G. 1998. Ultrasonography of the thyroid and parathyroid glands. Vet. Clin. N. Am., Small Anim. Pract. 28(4):973-991. <http://dx.doi. org/10.1016/S0195-5616(98)50085-X> <PMid:9698622>

Venzke W.G. 1975. Equine endocrinology, p.533-550. In: Getty R. (Ed.), Sisson and Grossman's the anatomy of the domestics animals. 5th ed. W.B. Saunders, Philadelphia.

Ueki H., Kowatari Y., Oyamada T., Oikawa M. \& Yoshikawa H. 2004. Nonfunctional C-cell adenoma in aged horses. J. Comp. Pathol. 131(2/3):157165. <http://dx.doi.org/10.1016/j.jcpa.2004.03.001><PMid:15276855> 